Asian J. Med. Biol. Res. 2016, 2 (2), 190-195; doi: 10.3329/ajmbr.v2i2.29060

\author{
Asian Journal of \\ Medical and Biological Research \\ ISSN 2411-4472 (Print) 2412-5571 (Online) \\ www.ebupress.com/journal/ajmbr
}

\title{
Article \\ Effect of heat stress on milk production and its composition of Holstein Friesian crossbred dairy cows
}

\author{
Mahmud Al Reyad ${ }^{\mathrm{a}}$, Md. Abid Hasan Sarker ${ }^{\mathrm{a}}$, Md. Elias Uddin, Raihan Habib and Md. Harun-ur-Rashid* \\ Department of Dairy Science, Bangladesh Agricultural University, Mymensingh-2202, Bangladesh \\ ${ }^{a}$ Mahmud Al Reyad and Md. Abid Hasan Sarker contributed equally to this paper
}

*Corresponding author: Professor Dr. Md. Harun-ur-Rashid, Department of Dairy Science, Bangladesh Agricultural University, Mymensingh-2202, Bangladesh. Phone: +8801720381581; Fax: +8809161510; Email: mrashid_69@yahoo.com

Received: 22 May 2016/Accepted: 20 June 2016/ Published: 30 June 2016

\begin{abstract}
The aim of this research was to observe the effect of heat stress on milk yield and milk compositions of Holstein Friesian crossbred (HF) dairy cows. To fulfill the objectives, a total of 9 Holstein Friesian crossbred cows were selected for this study. Green grasses (German, Para) were supplied adlibitum and concentrate feeds (mixture of wheat bran, rice polish, mustard oil cake, di-calcium phosphate and salt) were supplied at the rate of $2.0 \mathrm{~kg} / \mathrm{day} / \mathrm{cow}$. Management practices for all the cows were similar following the BAU Dairy farm practices. Data were collected on milk yield $(1 / \mathrm{h} / \mathrm{d})$, relative humidity $(\%)$ and barn temperature $\left({ }^{\circ} \mathrm{C}\right)$. The obtained temperature humidity index (THI) of July, August, September and October were 84.95, 81.99, 81.40 and 79.57, respectively. The highest THI was found in July which indicated higher heat stress during this month. A significant difference $(\mathrm{p}<0.05)$ in milk yield of cows was found among different months of July to October. The highest milk yield $(6.10 \pm 0.50 \mathrm{l} / \mathrm{h} / \mathrm{d})$ was found in October among observed months. The compositions of milk such as total solids (TS), solids-not-fat (SNF), fat, protein, lactose, and ash also differed significantly ( $\mathrm{p}<0.01$ ). The highest values (\%) of TS, SNF, fat, protein, lactose and ash content of milk were found in October as 12.63, $8.80,3.83,3.69,4.39$ and 0.72 , respectively and lowest values (\%) were in July as $12.20,8.50,3.71,3.50,4.30$ and 0.69 , respectively due to the high THI value. From these results, it is concluded that heat stress has strong effect on milk yield and milk composition of HF cows in Bangladesh. Management strategies are needed to minimize heat stress and attain optimal dairy animal performance.
\end{abstract}

Keywords: heat stress; temperature; relative humidity; milk production; milk composition

\section{Introduction}

Dairy cattle are important part of the livestock sector in Bangladesh. Total cattle population is about 24 million and total milk yield is 3518800 tons (FAOSTAT, 2013). Dairy cows in several tropical and subtropical regions are exposed to high ambient temperatures (Ta), relative humidity $(\mathrm{RH})$ and solar radiation for long periods. These reduce the capacity of the dairy cow to dissipate heat, resulting in heat stress. For this reason, cow develops various physiological processes to cope with the stress. These responses have unenthusiastic effects on the physiology and milk yield of the cow. Dairy cows are more sensitive to climatic variations that significantly influence their ability to produce milk. Heat stress is usually related with a turn down of the productive performances as they concentrate on thermo-regulation mechanisms to avoid hyperthermia (Nardone et al., 2006). Heat stress is negatively associated with various dairy characters including milk yield and therefore is a considerable financial burden in many milk producing areas of the world (St. Pierre et al., 2003). Thermolysis conducts to metabolic changes that reduce the feed intake; this is the key reason of turn down of milk production. High yielding dairy cows are extremely susceptible to heat stress, as well as cows during peak 
production. When the environmental temperature is above the body temperature, the cows countenance the risk of heat stress and milk production can be decreased by as much as 50\% (Ben Salem and Bouraoui, 2009). The comfortable environmental temperature for dairy cattle ranges between 5 to $25{ }^{\circ} \mathrm{C}$ which is also known as the thermal comfort zone (McDowell, 1976). The objective of this study was to monitor the trend of daily milk yield as function of ambient temperature and relative humidity during the months of summer season (JulyOctober) at BAU Dairy farm and to analyze the composition of summer milk produced by Holstein Friesian crossbred dairy cows.

\section{Materials and Methods}

\subsection{Study place}

The study place was at BAU Dairy Farm under the department of Dairy science, Bangladesh Agricultural University, Mymensingh-2202. This farm was selected purposively for the convenience (communication and research facilities) of the research work.

\subsection{Selection of dairy cows}

A total of 9 Holstein Friesian crossbred dairy cows were selected for this research. Dairy cows were selected based on the age (4 to 5 years), the stage of lactation (1 to 2 months) and number of lactation (1 to 3 ). The average live weight of the dairy cows was $301.77 \pm 22.12 \mathrm{~kg}$. Since the experimental dairy cows were rearing with the other dairy cows in the dairy farm, the selected dairy cows were marked by using number for easy identification and taking care separately.

\subsection{Feeding roughages and concentrates to the dairy cows}

Collected green grasses (German and Para) were supplied to the dairy cows at adlibitum twice a day, $2.0 \mathrm{~kg} / \mathrm{day}$ of concentrate feeds (mixture of wheat bran, rice polish, mustard oil cake, DCP and salt) were supplied to the cows twice a day before milking. Management practices of all the dairy cows were similar.

\subsection{Milk yield record}

Milking was performed two times in a day as in the morning at 6.00 to 6.30 am and afternoon at 4.00 to 5.00 pm. Milk yields $(1 / \mathrm{h} / \mathrm{d})$ of cows were recorded daily on record sheet.

\subsection{Temperature and humidity record}

The ambient temperature $\left({ }^{\circ} \mathrm{C}\right)$ and relative humidity $(\%)$ were recorded daily by using thermo-hygrometer. The temperature and humidity were recorded for 4 months during July to October, 2015.

\subsection{Analysis of milk compositions}

Milk compositions (TS, SNF, fat, protein, lactose and ash) were analyzed by using Lactoscan milk analyzer (Milktronic Ltd., 600 Stara Zagora, Bulgaria) in the chemistry and technology Laboratory, Bangladesh Agricultural University.

\subsection{Temperature humidity index (THI)}

Collected data included average, minimum and maximum monthly temperatures and relative humidity. The THI index was calculated for all four months using the formula developed by Kibler (1964). Formula is as follows: $\mathrm{THI}=1.8 \times \mathrm{Ta}-(1-\mathrm{HR}) \times(\mathrm{Ta}-14.3)+32$,

Where: Ta=Mean ambient temperature in ${ }^{0} \mathrm{C}$; HR $=$ Mean Relative Humidity on the basis to the unit value. Estimated THI values were used to identify heat stress to examine the monthly variation of THI.

\subsection{Statistical analysis}

The data were subjected to statistical analysis using one way ANOVA by complete randomized design (CRD) in SPSS-16, Version 2007. Duncan multiple range test (DMRT) was done to determine the degree of significance between the means.

\section{Results and Discussion}

\subsection{Average ambient temperature $\left({ }^{0} \mathrm{C}\right)$, relative humidity $(\%)$ and $\mathrm{THI}$ index}

The average ambient temperature $\left({ }^{\circ} \mathrm{C}\right)$, relative humidity $(\%)$ and temperature humidity index are shown in Table 1. The THI of July, August, September and October were 84.95, 81.99, 81.40 and 79.57, respectively. The highest temperature humidity index was found for July indicating higher heat stress on dairy cows during this 
month followed by August, September and the lowest in October. Average THI values of observed months ranged between 84.95 and 79.57, suggesting the lack of cold stress, but confirm the presence of heat stress for the four months period going from July to October (THI> 72). These high THI values indicate that most dairy herds are exposed to the negative effects of heat stress. THI for July to October also is shown in Figure 1. In July, the THI starts with 84.95 and finally ends with 79.57 in October. THI increased in accordance with the increased temperature $\left({ }^{\circ} \mathrm{C}\right)$ and humidity $(\%)$. The Figure indicated positive heat stress load considering temperature $\left({ }^{\circ} \mathrm{C}\right)$ and humidity $(\%)$ from July to October. The THI load provides a measure of the amount of heat stress an animal is under (St-Pierre et al., 2003). The upper critical THI above which animals suffer from heat stress varies by species and age. This THI threshold has been estimated to be about 70 humidity-adjusted degrees for lactating dairy cows, 72 degrees for growing-finishing hogs, 75 degrees for beef cows, and 78 degrees for broiler chickens (St-Pierre et al., 2003). The findings of this research work were greater than the suggested critical threshold of 72 for Holstein cows (Johnson, 1985). The upper critical temperature for Holsteins Friesian is $25^{\circ} \mathrm{C}$ (Berman et al., 1985). The findings of this research work support the findings results of Vecera et al., 2012. The mean temperature in hot period $(\mathrm{H})$, humidity and THI found in their study were $27.1{ }^{\circ} \mathrm{C}, 54.4 \%$ and 75 , respectively.

Table 1. Ambient temperature $\left({ }^{\circ} \mathrm{C}\right)$ and relative humidity (\%) during July to October, 2015 at BAU Dairy farm in Mymensingh, Bangladesh.

\begin{tabular}{lllc}
\hline \multirow{2}{*}{ Months } & Ambient Temperature $\left({ }^{\mathbf{0}} \mathbf{C}\right)$ & Relative humidity $(\%)$ & \multirow{2}{*}{ THI } \\
\cline { 2 - 3 } & Mean \pm SD & Mean \pm SD & 84.95 \\
\hline July & $30.69 \pm 0.53$ & $86 \pm 0.50$ & 81.99 \\
August & $29.09 \pm 1.08$ & $84 \pm 1.0$ & 81.40 \\
September & $28.90 \pm 1.25$ & $82 \pm 0.6$ & 79.57 \\
October & $27.86 \pm 0.52$ & $81 \pm 0.5$ & \\
\hline
\end{tabular}

THI=temperature humidity index

Table 2. Milk yield (litre) of the experimental HF crossbred dairy cows during July to October, 2015 at BAU Dairy farm in Mymensingh, Bangladesh.

\begin{tabular}{|c|c|c|c|c|c|c|c|c|c|c|c|c|c|}
\hline & Cow-1 & Cow-2 & Cow-3 & Cow-4 & Cow-5 & Cow-6 & Cow-7 & Cow-8 & Cow-9 & $\begin{array}{l}\text { Average milk } \\
\text { yield (litre) }\end{array}$ & $\begin{array}{l}\mathbf{p} \\
\text { value }\end{array}$ & $\mathbf{L S}$ & THI \\
\hline July & $\begin{array}{l}60 \pm \\
20\end{array}$ & $\begin{array}{l}5.00 \pm \\
0.10\end{array}$ & 0.20 & $\begin{array}{l}6.00 \pm \\
0.09\end{array}$ & $\begin{array}{l}5.40 \pm \\
0.08\end{array}$ & 0.10 & $\begin{array}{l}4.10 \pm \\
0.50\end{array}$ & 0.62 & $\begin{array}{l}5.50 \pm \\
0.30\end{array}$ & 0.61 & \multirow{4}{*}{0.01} & & 84.95 \\
\hline August & $\begin{array}{l}4.90 \pm \\
0.31\end{array}$ & $\begin{array}{l}5.80 \pm \\
0.25\end{array}$ & $\begin{array}{l}5.60 \pm \\
0.10\end{array}$ & $\begin{array}{l}6.70 \pm \\
0.12\end{array}$ & $\begin{array}{l}5.70 \pm \\
0.20\end{array}$ & $\begin{array}{l}5.60 \pm \\
0.26\end{array}$ & $\begin{array}{l}4.70 \pm \\
0.22\end{array}$ & $\begin{array}{l}5.40 \pm \\
0.23\end{array}$ & $\begin{array}{l}5.80 \pm \\
0.11\end{array}$ & $\begin{array}{l}5.58^{\mathrm{ab}} \pm \\
0.57\end{array}$ & & & 31.99 \\
\hline Septe & $\begin{array}{l}5.40 \pm \\
0.14\end{array}$ & $\begin{array}{l}5.90 \pm \\
0.17\end{array}$ & $\begin{array}{l}6.00 \pm \\
0.20\end{array}$ & $\begin{array}{l}6.90 \pm \\
0.11\end{array}$ & $\begin{array}{l}5.90 \pm \\
0.21\end{array}$ & $\begin{array}{l}5.80 \pm \\
0.21\end{array}$ & $\begin{array}{l}4.90 \pm \\
0.13\end{array}$ & $\begin{array}{l}5.80 \pm \\
0.10\end{array}$ & $\begin{array}{l}5.80 \pm \\
0.14\end{array}$ & $\begin{array}{l}5.82^{\mathrm{a}} \pm \\
0.52\end{array}$ & & & 1.40 \\
\hline October & $\begin{array}{l}5.50 \pm \\
0.12 \\
\end{array}$ & $\begin{array}{l}6.30 \pm \\
0.18 \\
\end{array}$ & $\begin{array}{l}6.50 \pm \\
0.22\end{array}$ & $\begin{array}{l}7.00 \pm \\
0.18\end{array}$ & $\begin{array}{l}6.20 \pm \\
0.11 \\
\end{array}$ & $\begin{array}{l}6.00 \pm \\
0.15 \\
\end{array}$ & $\begin{array}{l}5.30 \pm \\
0.12 \\
\end{array}$ & $\begin{array}{l}5.90 \pm \\
0.21 \\
\end{array}$ & $\begin{array}{l}6.20 \pm \\
0.13 \\
\end{array}$ & $\begin{array}{l}6.10^{\mathrm{a}} \pm \\
0.50\end{array}$ & & & 79.57 \\
\hline
\end{tabular}

a, b, c Means with different superscript(s) in the same column differ significantly; LS=Level of Significance; *Significant at $1 \%$ level $(\mathrm{p}<0.05)$

Table 3. Milk composition (\%) of the experimental HF crossbred dairy cows during July to October, 2015 at BAU Dairy farm in Mymensingh, Bangladesh.

\begin{tabular}{lllllll}
\hline Month & TS & SNF & Fat & Protein & Lactose & Ash \\
\hline July & $12.20^{\mathrm{d}}$ & $8.50^{\mathrm{c}}$ & $3.71^{\mathrm{d}}$ & $3.50^{\mathrm{d}}$ & $4.30^{\mathrm{d}}$ & $0.69^{\mathrm{c}}$ \\
August & $12.39^{\mathrm{c}}$ & $8.67^{\mathrm{b}}$ & $3.75^{\mathrm{c}}$ & $3.60^{\mathrm{c}}$ & $4.34^{\mathrm{c}}$ & $0.70^{\mathrm{c}}$ \\
September & $12.51^{\mathrm{b}}$ & $8.68^{\mathrm{b}}$ & $3.80^{\mathrm{b}}$ & $3.65^{\mathrm{b}}$ & $4.35^{\mathrm{b}}$ & $0.71^{\mathrm{b}}$ \\
October & $12.63^{\mathrm{a}}$ & $8.80^{\mathrm{a}}$ & $3.83^{\mathrm{a}}$ & $3.69^{\mathrm{a}}$ & $4.39^{\mathrm{a}}$ & $0.72^{\mathrm{a}}$ \\
\hline p value & 0.00 & 0.00 & 0.00 & 0.00 & 0.00 & 0.001 \\
\hline Level of significance & $* *$ & $* *$ & $* *$ & $* *$ & $* *$ & $* *$ \\
\hline
\end{tabular}

a, b, c, d Means with different superscript(s) in the same column differ significantly; **Significant at $1 \%$ level $(\mathrm{p}<0.01)$ 


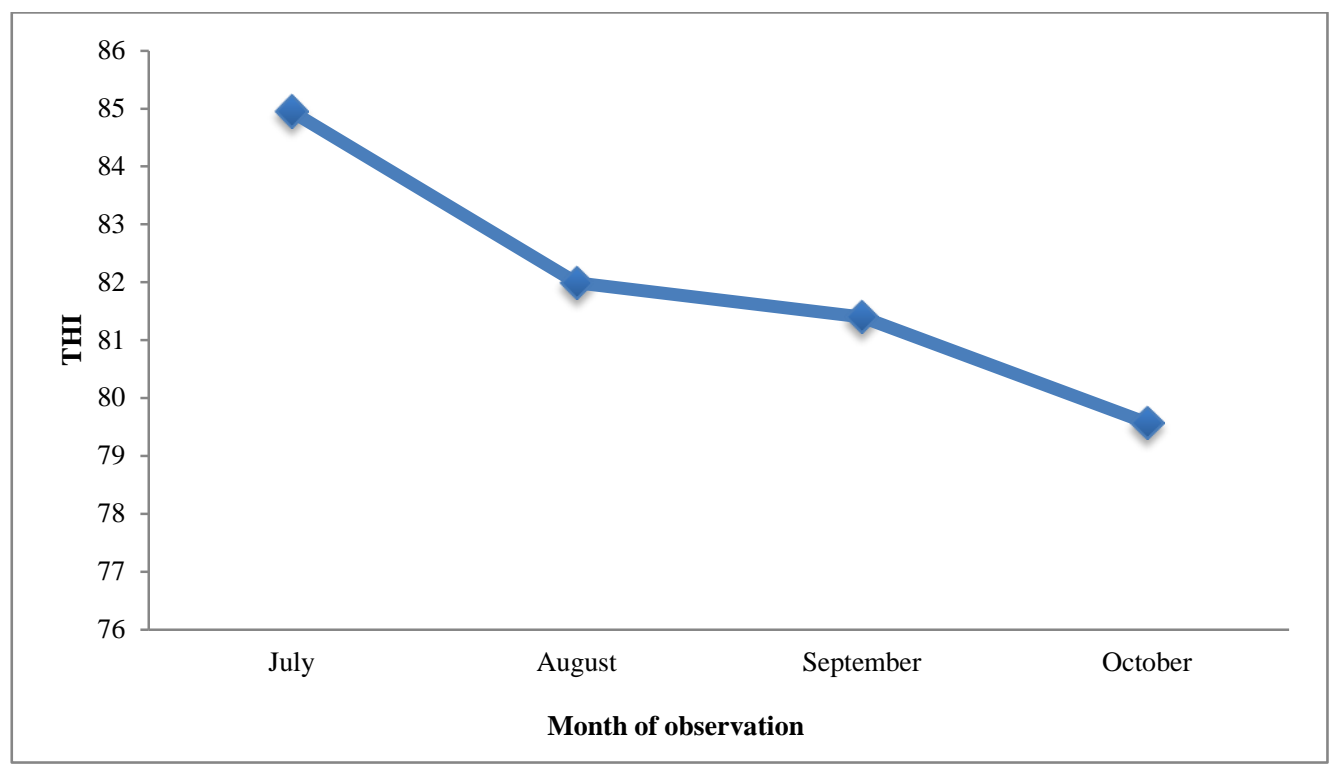

Figure 1. Temperature humidity index during July to October, 2015 at BAU Dairy farm in Mymensingh, Bangladesh.

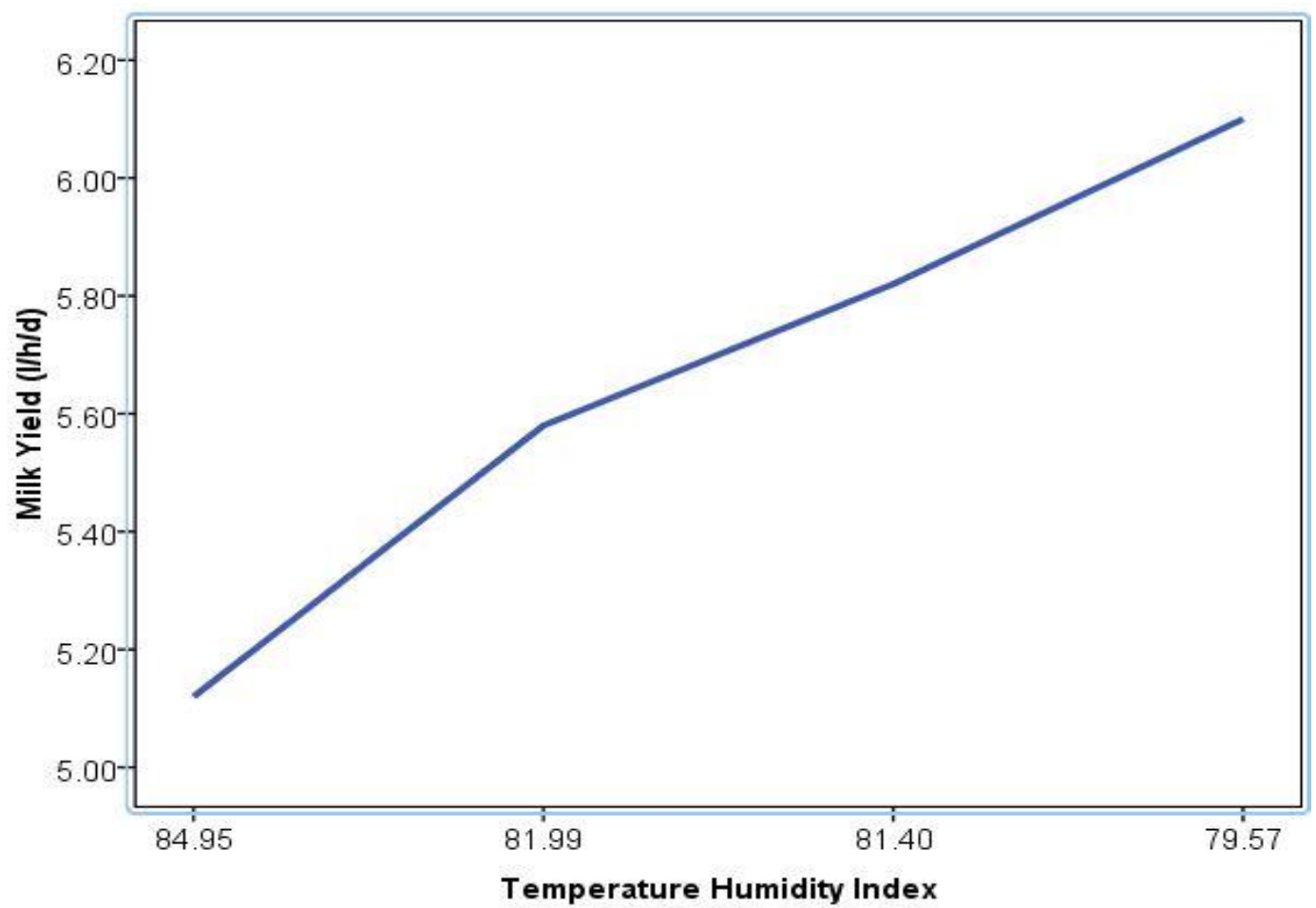

Figure 2. Relationship between temperature humidity index and milk yield during July to October, 2015 at BAU Dairy farm in Mymensingh, Bangladesh.

\subsection{Milk production}

The average milk yields of cows were $5.12 \pm 0.61,5.58 \pm 0.57,5.82 \pm 0.52$ and $6.10 \pm 0.50$ for July, August, September and October, respectively which are presented in Table 2. Milk yield of cows differed significantly $(\mathrm{p}<0.05)$ among the different months. The average highest milk yield $(6.10 \pm 0.05 \mathrm{l} / \mathrm{h} / \mathrm{d})$ was found in October and lowest $(5.12 \pm 0.61 \mathrm{l} / \mathrm{h} / \mathrm{d})$ was in July. It clearly indicates a negative relationship between milk production and THI. Indeed, the increased THI exposed heat stress which in turn reduced milk yield. From July to October THI decreased from 84.95 to 79.57 where the milk production increased from $5.12 \pm 0.61 \mathrm{l} / \mathrm{h} / \mathrm{d}$ to $6.10 \pm 0.05$ 1/h/d. Milk yield of September and October was statistically ( $>0.05)$ similar as the THI of those two months was near to similar. Bouraoui et al. (2002) found that daily THI was negatively correlated to milk yield, with the 
increased THI value from 68 to 78 , milk production decreased by $21 \%$ and DMI by $9.6 \%$. Milk yield decreased by $0.41 \mathrm{~kg}$ per cow per day for each point increase in the THI values above 69 . Ambient temperature and humidity join to decrease dry matter intake (DMI) in dairy cows as a physiological means of regulating internal body temperature. This is accomplished by decreasing rumen fermentation and the metabolic rate (Moody EG, 1971). A reduction in DMI decreases the nutrients accessible for milk synthesis. Milk production turn down and many lactation parameters are affected (Bauman et al., 1980 and Smith et al., 1982). Dairy cows instinctively reduce feed intake throughout the period of heat stress, and this reduction could boost up as weather becomes hotter. Typically, early lactating and high producing cows are more directly and severely affected than late lactating or low producing cows. The reduction in nutrient intake has been identified as a major cause of reducing milk synthesis because it has been associated to a negative energy balance state (Wheelock et al., 2010). Nevertheless, so as to know the exact contribution of decline feed intake to the overall reduced milk yield during heat stress, Rhoads et al. (2009) used a group of thermo-neutral pair-fed dairy cows to abolish the confounding effects of nutrient intake. The cows were in mid-lactation and were either subjected to a THI of 80 units for $16 \mathrm{~h} / \mathrm{d}$ (cyclically heat-stressed) during $9 \mathrm{~d}$ or kept under a THI of 64 units during $24 \mathrm{~h} / \mathrm{d}$ (constant thermo neutral conditions). In figure 2, a clear relationship was found between milk yield and THI. Milk yield increased from July to October in accordance with the decreased THI. The lowest milk yield $(5.12 \pm 0.61 \mathrm{l} / \mathrm{h} / \mathrm{d})$ was found against the highest THI (84.95) and the highest milk yield $(6.10 \pm 0.05 \mathrm{l} / \mathrm{h} / \mathrm{d})$ was found against the lowest THI (79.57). From the study it is clear that milk yield decreased with increased heat stress and viceversa.

\subsection{Composition}

Compositions of milk (TS, SNF, fat, protein, lactose, and ash) differed significantly $(\mathrm{p}<0.01)$ among four different months of July to October, are shown in Table 3. TS, SN, fat, protein, lactose and ash content of milk were observed with higher value in October as $12.63,8.80,3.83,3.69,4.39$ and $0.72 \%$, respectively. In contrary, the lower TS, SNF, fat, protein, lactose and ash content of milk were observed in July as 12.20, 8.50, 3.71, 3.50, 4.30 and $0.69 \%$, respectively. SNF content of milk from August and September was found to be statistically similar. Heat stress in environments has been connected with reducing in milk constituents. Milk constituents were increased in accordance with the decreased THI. Knapp and Grummer (1991) reported a decreased milk composition with increased maximum daily temperature. Bouraoui et al. (2002) found that milk fat and milk protein were lower for the summer season. Ozrenk and Inci (2008) reported that milk fat, protein and total solids percentages in cow milk were highest during the winter and the lowest during the summer.

\section{Conclusions}

From the findings of this experiment, it is concluded that milk yield and milk composition of Holstein Friesian crossbred cows are influenced by heat stress during the summer period of July to October. Management strategies could be helpful to minimize heat stress through water sprinkle or other means to attain optimal performance of dairy cows.

\section{Acknowledgements}

The authors would like to thank the National Science and Technology Project-2015, Ministry of Science and Technology, The Government of the People's Republic of Bangladesh for providing financial support to conduct this research. The authors are grateful to the staffs of BAU dairy farm for their cooperation.

\section{Conflict of interest}

None to declare.

\section{References}

Bauman DE and WB Currie, 1980. Partitioning of nutrients during pregnancy and lactation: A review of mechanisms involving homeostasis and homeorhesis. J. Dairy Sci., 63: 1514-1529.

Ben Salem M and R Bouraoui, 2009. Heat Stress in Tunisia: Effects on dairy cows and potential means of alleviating it. S. Afr. J. Anim. Sci., 39: 256-259.

Berman A, YM Folman, M Kaim, Z Mamen, D Herz, A Wolfenson and Y Graber, 1985. Upper critical temperatures and forced ventilation effects for high-yielding dairy cows in a tropical climate. J. Dairy Sci., 68: 488-495.

Bouraoui R, M Lahmar, A Majdoub, M Djemali and R Belyea, 2002. The relationship of temperaturehumidity index with milk production of dairy cows in a Mediterranean climate. Anim. Res., 51: 479-491. 
Asian J. Med. Biol. Res. 2016, 2 (2)

FAOSTAT, 2013. Food and Agricultural Organization, United Nation, statistic division. URL: http://faostat3.fao.org/browse/Q/QA/E.

Johnson HD, 1985. Physiological responses and productivity of cattle, In: Stress physiology in livestock. Basic Principles, Ed. Yousef, M.K., Boca Raton, Florida, CRC Press, 1: 4-19.

Kibler HH, 1964. Environmental physiology and shelter engineering. LXVII. Thermal effects of various temperature humidity combinations on Holstein cattle as measured by eight physiological responses. No. 862.

Knapp DM and RR Grummer, 1991. Response of lactating dairy cows to fat supplementation during heat stress. J. Dairy Sci., 74: 2573-2579.

McDowell RE, NW Hooven, JK Camoens, 1976. Effects of climate on performance of Holsteins in first lactation. J. Dairy Sci., 59: 965-971.

Moody EG, PJ Van Soest, RE McDowell and GL Ford, 1971. Effect of high temperature and dietary fat on milk fatty acids. J. Dairy Sci., 54: 1457-1460.

Nardone A, B Ronchi, N Lacetera and U Bernabucci, 2006. Climatic effects on productive traits in livestock. Vet. Res. Commun., 30: 75-81.

Ozrenk E and SS Inci, 2008. The effect of seasonal variation on the composition of cow milk in Van Province. Pak. J. Nutri., 7: 161-164.

Rhoads ML, RP Rhoads, MJ Van Baale, RJ Collier, SR Sanders, WJ Weber, BA Croocker and LH Baumgard, 2009. Effects of heat stress and plane of nutrition on lactating Holstein Cows: production, metabolism, and aspects of circulating somatotropin. J. Dairy Sci., 90: 1986-1997.

Smith WA, B Harris, HH Van Horn, and CJ Wilcox, 1993: Effect of forage type on production of dairy cows supplemented with whole cottonseed, tallow, and yeast. J. Dairy Sci., 76: 205-215.

SPSS-16 (Statistical Package for Social Services), SPSS Inc. Released, 2007. SPSS for Windows, Version 16.0, Chicago, SPSS Inc).

St. Pierre NR, B Cobanov and G Schnitkey, 2008. Economic losses from heat stress by US livestock industries. J. Dairy Sci., 86: 52-77.

Vecera M, D Falta, G Chadek and K Machal, 2012. The effect of low and high barn temperatures on behaviour and performance of holstein dairy cows. Acta univ. agric. et silvic. Mendel. Brun., 6: 343-350.

Wheelock JB, RP Rhoads, MJ VanBaale, SR Sanders and LH Baumgard, 2010. Effect of Heat Stress on Energetic Metabolism in Lactating Holstein Cows. J. Dairy Sci., 93: 644-655. 